\title{
LC-ESI-MS analysis, antitumor and antioxidant activities of methanolic extract of Egyptian Allium kurrat
}

\author{
Heba Abdel-Hady*, Mortada Mohamed El-Sayed, Mahfouz Mohamed Abdel-Gawad, Eman Ahmed El-Wakil, \\ El-Sayed Saleh Abdel-Hameed, Ezzat El-Sayed Abdel-Lateef \\ Medicinal Chemistry Laboratory, Theodor Bilharz Research Institute, Kornish El-Nile-Warrak El-Hadar, Imbaba, Giza 12411, Egypt.
}

\begin{tabular}{l}
\hline ARTICLE INFO \\
\hline Article history: \\
Received on: 05/03/2018 \\
Accepted on: 09/05/2018 \\
Available online: 30/07/2018 \\
\hline Key words: \\
Allium kurrat, antioxidant, \\
HePG2, Coca-2, LC-ESI- \\
MS, phenolic compounds.
\end{tabular}

\section{INTRODUCTION}

Cancer is not only a human disease but it is a serious problem affects the survival of all human beings. It has shown economic and social changes to the healthcare system (Hagag et al., 2011; El-Hady et al., 2014). Cancer is a set of diseases expressed as the abnormal control in cell growth. Normal cells often repair mutations in their DNA but once they cannot make the repairs, the cells become cancerous (Krishnamurthi, 2007). Cancer includes several types among them hepatic carcinoma (HCC) which represents the $5^{\text {th }}$ most common cancer worldwide and the $3^{\text {rd }}$ cause of cancer disease worldwide (El-Serag, 2002) while, colon cancer is the second cause of cancer death worldwide (Ricci-Vitiani et al., 2007).

Oxidative stress which is an intra or extracellular disorders that lead to generating ROS (reactive oxygen species). ROS contains hydroxyl radicals, hydrogen peroxide and singlet

${ }^{*}$ Corresponding Author

Heba Abdel-Hady, Theodor Bilharz Research Institue, warrak ElHaddar,Giza,12411Egypt.E-mail:h_hady10@yahoo.com oxygen that can cause oxidative damage to essential cellular constituents. Also, free radicals produced to contribute to several diseases as liver cirrhosis, diabetes, and cancer (El-Hady et al., 2014). Compounds that have the ability to scavenge these free radicals show great potential improvement in these diseases. So, in recent years, there are excessive efforts to find natural antioxidant from plants to exchange synthetic ones that have been limited according to their carcinogenicity (Sasaki et al., 2002).

Pure natural compounds, as well as different crude extracts from plants, have been reported as natural antioxidants according to their free radical scavenging ability (Chang et al., 2008). Medicinal plants used widely as traditional medicine in the treatment of many diseases. There is a huge scientific confirmation that nutritive and non-nutritive plants can inhibit, reverse and prevent carcinogenesis (Krishnamurthi, 2007).

There are about 500 species of Allium genus, garlic, onions, and leeks are the most widely used ones (Malairajan et al., 2006). Allium species are rich sources of phytonutrients and many pharmacological activities including cholesterol lowering, anti-hypertensive, anti-spasmodic, anti-bacterial, antiviral, 
antimicrobial and anticancer effects. They are also the richest sources of naturally occurring flavonoids that help us in intake a high level of phenolic compounds through the daily diet (Ghavam-Haghiand Dinani, 2017). The most popular species in Egypt and Eastern Mediterranean countries is Allium kurrat. It has been used in medicine and has been considered efficient food in several countries contains proteins, fats, carbohydrates, minerals, and vitamins. Therefore, A. kurrat is a dietary plant of low toxicity and therapeutic values (Sharaf et al., 1969; Adao et al., 2011; Abd El-Rehem \& Ali, 2013).

The present study was designed to estimate the total phenolic and flavonoid contents of the methanolic extract and derived fractions from it of Allium kurrat. The antioxidant and cytotoxic activities of these extracts were evaluated. Also, the chemical constituents of the methanolic extract and the ethyl acetate fraction were identified using LC-ESI-MS analysis.

\section{MATERIALS AND METHODS}

\section{Chemicals}

ABTS (2-2'azinobis (3-ethylbenzthiazoline-6-sulphonic acid), DPPH (1,1diphenyl-2-picryl hydrazyl radical), and Folin-Ciocalteu reagent were purchased from Sigma-Aldrich (Germany). Sodium hydrogen phosphate, Potassium persulphate, Sodium nitrite, Sodium hydroxide, Ammonium molybdate, Sodium bicarbonate and Aluminum chloride were purchased from Merck (Germany). Gallic acid, Rutin, and Ascorbic acid were purchased from Sigma-Aldrich (USA). $\alpha$-Tocopherol (Vitamin E) was purchased from Sigma-Aldrich (England).

\section{Plant material}

Arial parts of Allium kurrat were collected from a regional market in Giza, Egypt. The plant was identified by Dr. Rim Samir Hamdy, Professor of Plant Taxonomy, Faculty of Science, Cairo University. The voucher specimen of the plant under investigation was stored in Medicinal Chemistry Department, Theodor Bilharz Research Institute.

\section{Extraction and fractionation}

500 gram of the plant dry powder was extracted with $85 \%$ methanol and then concentrated under vacuum by using a rotatory evaporator (BUCHI, Switzerland). The dried methanolic extract was defatted by petroleum ether. The aqueous defatted methanolic extract was fractionated by dichloromethane $\left(\mathrm{CH}_{2} \mathrm{Cl}_{2}\right)$, ethyl acetate (EtOAc), and n-butanol (n-BuOH). The methanolic extract and the fractions were kept away from moisture for the present study.

\section{Determination of total phenolic content}

The phenolic content of the tested extracts was evaluated using the spectrophotometric method described by El-Sayed et al. (2017). $0.5 \mathrm{~mL}$ of the extract $(250 \mu \mathrm{g} / \mathrm{mL}), 2.5 \mathrm{~mL}$ of FolinCiocalteus reagent mixed with $\mathrm{H}_{2} \mathrm{O}(10: 90)$ and $2.5 \mathrm{mLNaHCO}_{3}$ (7.5\%). The blank sample contains $0.5 \mathrm{~mL}$ of $\mathrm{MeOH}, 2.5 \mathrm{~mL}$ of $10 \%$ Folin-Ciocalteus reagent and $2.5 \mathrm{~mL} \mathrm{7.5 \%} \mathrm{NaHCO}_{3}$ in $\mathrm{H}_{2} \mathrm{O}$ All mixtures were shaken and incubated at $45^{\circ} \mathrm{C}$ for $45 \mathrm{~min}$. the absorbance was recorded at $765 \mathrm{~nm}$ versus a blank sample and gallic acid as the standard. The experiment was achieved in triplicate. The total phenolic content was expressed in terms of mg GAE eq./g extract.

\section{Determination of total flavonoid content}

The content of flavonoid was determined using a colorimetric assay reported by El-Sayed et al. (2017). $0.5 \mathrm{~mL}$ of each extract was dissolved in $2 \mathrm{ml} \mathrm{H}_{2} \mathrm{O}$ and $150 \mu \mathrm{L}$ of $5 \% \mathrm{NaNO}_{2}$ for $6 \mathrm{~min}$, then $150 \mu \mathrm{L}$ of $10 \% \mathrm{AlCl}_{3}$ was added and left to stand for 5 min then added of $2 \mathrm{~mL}$ of $4 \% \mathrm{NaOH}$ and the mix was completed up to $5 \mathrm{~mL}$ with distilled water. The mix was incubated at $25-27^{\circ} \mathrm{C}$ for $15 \mathrm{~min}$. the absorbance was measured at $510 \mathrm{~nm}$ versus a blank sample, and rutin was used as the standard. The total flavonoid content was expressed as mg RE eq./g extract. The experiment was achieved 3 times and all chemicals $\left(\mathrm{NaNO}_{2}, \mathrm{AlCl}_{3}\right.$, and $\mathrm{NaOH}$ were dissolved in water).

\section{Antioxidant assays}

\section{$D P P H$ radical scavenging activity}

The antioxidant activity of the tested extract was evaluated using DPPH free radical scavenging method (Akroum et al., 2010). $2 \mathrm{~mL}$ of each plant extract dissolved in methanol was mixed with $2 \mathrm{~mL}$ of DPPH in $\mathrm{MeOH}(0.1 \mathrm{mmol} / \mathrm{L})$. The control only contained solvent and DPPH. The mixtures were shaken and kept in dark for $30 \mathrm{~min}$ at $37^{\circ} \mathrm{C}$. The absorbance was measured at $517 \mathrm{~nm}$. The experiment was achieved in triplicates. The DPPH scavenging activity was calculated from this equation.

$\%$ DPPH scavenging activity $=[$ (control absorbance sample absorbance) $/($ control absorbance $)] \times 100$

\section{ABTS radical scavenging activity}

The plant extract can able to quench $\operatorname{ABTS}^{++}$(2-2'azinobis (3-ethylbenzthiazoline-6-sulphonic acid). The concentrated reagent solution was designed by dissolving $9.6 \mathrm{mg}$ ABTS in 2.5 $\mathrm{mL}$ water and then adding $110 \mu$ Lof potassium persulphate $(37.5$ $\mathrm{mg} / \mathrm{mL}$ ) dissolved in water. The stock solution was kept in the darkroom for 12-16 hours to produce $\mathrm{ABTS}^{++}$radical cation. The $\mathrm{ABTS}^{++}$solution was diluted by $\mathrm{MeOH}$ till the absorbance reach value between 0.7 and 0.8 at wavelength $734 \mathrm{~nm}$. Subsequently, $100 \mu \mathrm{L}$ of aqueous or alcoholic plant extract (according to solubility) was added to $1 \mathrm{~mL}$ of work solution, and it was measured exactly after $2.5 \mathrm{~min}$. Also, an appropriate solvent blank was measured. Calibration curve for $\mathrm{ABTS}^{++}$was obtained using Trolox $^{\circledR} \quad$ (6-hydroxy-2,5,7,8-tetramethylchroman-2-carboxylic acid) as standard. The experiment was carried out in triplicates. Results were expressed in terms of mmol Trolox ${ }^{\circledR}$ eq./100 g dry weight of plant extract (El-Sayed et al., 2015).

\section{Total antioxidant capacity}

The total antioxidant capacity of the tested extract was determined by Saeed et al. (2012) and Abdel-Hady et al. (2014). An aliquot of $0.1 \mathrm{~mL}$ of sample $(200 \mu \mathrm{g} / \mathrm{mL})$ solution was mixed with $1 \mathrm{~mL}$ of reagent solution $(0.6 \mathrm{M}$ sulphuric acid, $28 \mathrm{mM}$ sodium phosphate and $4 \mathrm{mM}$ ammonium molybdate). Blank was contained $1 \mathrm{~mL}$ of the reagent solution and nearly volume of the same solvent used for the samples. The tubes were capped and 
incubated at $95^{\circ} \mathrm{C}$ for $90 \mathrm{~min}$. After the samples had cooled to $25-27^{\circ} \mathrm{C}$, the absorbance of the mix was measured at $695 \mathrm{~nm}$ versus the blank and ascorbic acid was used as the standard. The experiment was repeated for 3 times. The antioxidant activity of the extracts was expressed as mg AAE eq./g extract.

\section{Cytotoxic assay}

\section{Cell culture}

Colon cancer (Caco-2) and Liver cancer (HepG2) cell lines were obtained, and cultured in the cell culture lab (CURP), Faculty of Agriculture, Cairo University. Also, the in-vitro cytotoxic assay was performed there.

\section{Neutral Red (NR) assay}

The NR assay is one of common sense used cytotoxic assays. It depends on measuring the lysosomal activity of the cells (Repetto et al., 2008). The methanol extract, Ethyl acetate and n-butanol fractions of Allium kurrat were tested at concentrations ranged from 10 to $200 \mu \mathrm{g} / \mathrm{mL}$ for HepG2 while their concentrations for Coca-2 were ranged from 50 to $600 \mu \mathrm{g} / \mathrm{mL}$. HepG2 and Coca-2 cells were seeded in 96-well plates at concentrations of $1 \times 10^{4}$ cells/well. $100 \mu \mathrm{L}$ of PBS was dispensed into the peripheral wells and the plate incubated at $37^{\circ} \mathrm{C}, \mathrm{CO}_{2}$ and humidified atmosphere in a sterile environment until half-confluent monolayer formed. The $200 \mu \mathrm{L}$ of treatment medium (serum-free medium) was added in an independent manner to the cells. $100 \mu \mathrm{L}$ of neutral red (NR) dye was added to each well then was incubated for 2 hrs. Cells were washed by $100 \mu \mathrm{L}$ of PBS and $150 \mu \mathrm{L}$ of neutral red destain solution was added on microtiter shaker for at least 10 min or until all neutral red dye that has been extracted formed the homogeneous solution. Measure the optical density (OD) of NR extract by spectrophotometer at $530 \mathrm{~nm}$ and $640 \mathrm{~nm}$ respectively. The treatment medium acts as a negative control. The experiment was achieved 3 times. The results represent $\mathrm{IC}_{50}$ is the percentage of inhibitory concentration of cell viability.

\section{HPLC-ESI-MS analysis}

(5 $\mathrm{mg} / \mathrm{mL}$ ) solution of the methanolic extract and ethyl acetate fraction of $A$. kurrat was prepared and filtered using a membrane disc filter $(0.45 \mu \mathrm{m})$ then analyzed by liquid chromatography coupled with electrospray ionization mass spectrometry (LC-ESI-MS) according to the method described by Abdel-Lateef et al. (2016) by using HPLC analytical grade solvent mixture of $\mathrm{CH}_{3} \mathrm{CN} / \mathrm{MeOH} / \mathrm{H}_{2} \mathrm{O}$ (1: 1: 2; v/v/v), Analysis was performed using HPLC system (Waters Alliance 2695, Waters, USA) and mass analyzer (Waters 3100). $20 \mu \mathrm{L}$ of a sample was injected into the HPLC instrument equipped with reverse phase C-18 column (Phenomenex $250 \mathrm{~mm}, 5 \mu \mathrm{m}$ particle sizes). The flow rate of $0.4 \mathrm{~mL} / \mathrm{min}$ using gradient mobile phase comprising two solvents: Solvent A contains water acidified with $0.1 \%$ formic acid and solvent $\mathrm{B}$ is $\mathrm{CH}_{3} \mathrm{CN} / \mathrm{MeOH}(1: 1 ; \mathrm{v} / \mathrm{v})$ acidified with $0.1 \%$ formic acid. Elution was performed using the following gradient: $5 \% \mathrm{~B} ; 0-5 \mathrm{~min}, 5-10 \% \mathrm{~B} ; 5-10 \mathrm{~min}, 10-50 \% \mathrm{~B}$; $10-55 \mathrm{~min}$, $50-95 \% \mathrm{~B}$; 55-65 min, and 5\% B; 65-70 min. The parameters for analysis were carried out using a negative ion mode as follows; source temperature $150^{\circ} \mathrm{C}$, cone voltage $50 \mathrm{eV}$, capillary voltage $3 \mathrm{kV}$, desolvation temperature $350^{\circ} \mathrm{C}$, cone gas flow $50 \mathrm{~L} / \mathrm{h}$, and desolvation gas flow $600 \mathrm{~L} / \mathrm{h}$. Mass spectra were detected in the ESI negative ion mode between $\mathrm{m} / z$ 50-1000. The peaks and spectra were processed using the Maslynx 4.1 software and tentatively identified by comparing its retention time (Rt) and mass spectrum with reported data.

\section{RESULTS AND DISCUSSION}

\section{Total phenolic and flavonoid contents}

The flavonoid and phenolic compounds are the main components of many plants. It has been reported that they have therapeutic and protective properties to cure many diseases because of these compounds possess major of hydroxyls group which responsible for the free radical scavenging activity. The obtained total phenolic and flavonoid contents from any plant depend on the ability of the used solvent in the extraction process (Marinova et al., 2005; Deepa et al., 2009; Atanassova et al., 2011; Safaeian et al., 2017).

In this study, the results showed in Table 1 that the methanolic extract and derived fractions from it exhibit high phenolic and flavonoid contents. The ethyl acetate and n-butanol fractions of $A$. kurrat have the highest phenolic and flavonoid contents $(127.45 \pm 0.71$ and $116.43 \pm 2.05$ (mg GAE eq./g extract) and $98.55 \pm 1.87$ and $91.73 \pm 0.091$ (mg RE eq./g extract)) respectively. On the contrary, the water residue had the lowest phenolic and flavonoid contents $(30.45 \pm 0.76$ (mg GAE eq./g extract) and $15.21 \pm 0.60$ (mg RE eq./g extract). The order of other extracts was methanol extract $<$ dichloromethane fraction $(58.43 \pm$ 0.68 and $83.05 \pm 1.07$ (mg GAE eq./g extract) respectively. These results are agreed with previous studies on Allium species which reported that the different Allium extracts have a high content of phenolic and flavonoid (Škerget et al., 2009; Lu et al., 2011; Abdel-Gawad et al., 2014; Safaeian et al., 2017).

Table 1: Total phenolic and flavonoid contents of the methanolic extract and derived fractions from it of Allium kurrat.

\begin{tabular}{ccc}
\hline Extract/Fraction & $\begin{array}{c}\text { Total phenols } \\
\text { (mg GAE/g of ext.) }\end{array}$ & $\begin{array}{c}\text { Total flavonoids } \\
\text { (mg RE/g of ext.) }\end{array}$ \\
\hline MeOH extract & $96.43 \pm 0.68$ & $55.51 \pm 2.80$ \\
$\mathrm{CH}_{2} \mathrm{Cl}_{2}$ fraction & $80.05 \pm 1.07$ & $45.14 \pm 0.09$ \\
EtOAc fraction & $127.45 \pm 0.071$ & $98.55 \pm 1.87$ \\
$\mathrm{BuOH}$ fraction & $116.43 \pm 2.05$ & $91.73 \pm 0.091$ \\
$\mathrm{H}_{2} \mathrm{O}$ residue & $53.45 \pm 0.76$ & $27.21 \pm 0.60$ \\
\hline
\end{tabular}

The data represents as mean \pm standard deviation.

\section{Antioxidant activity of plant extract}

Different free radicals as hydroxyl groups, peroxyl radicals, and single oxygen, etc. have a harmful effect due to their ability to oxidize cell components and causing different diseases (Aqil et al., 2006; Bozin et al., 2008). So, the antioxidant property plays an important role in reducing chronic diseases like cancer and cardiovascular diseases by scavenging the free radicals. Plants are primary and the main sources of antioxidants as polyphenolic compounds and saponins (Aqil et al., 2006; Bozin et al., 2008). 
In this study, evaluation the antioxidant activity of the methanolic extract and the tested fractions of A. kurrat by using three methods including DPPH, ABTS radical scavenging activity, and total antioxidant capacity assays.

\section{DPPH radical scavenging assay}

The DPPH is a stable radical. It was commonly used to exam the ability of compounds as free-radical scavengers or hydrogen donors and also, to evaluate the antioxidant activity of plant extracts and foods (Akroum et al., 2010; Kaur et al., 2016; Abdel-Hady et al., 2017). The results of this study in Table 2 proved that the methanolic extract and different fractions derived from it have antioxidant property. The ethyl acetate fraction has the highest activity than other extracts $(41.56 \pm 1.06 \mu \mathrm{g} / \mathrm{mL})$ followed by butanolic fraction $(56.13 \pm 1.64 \mu \mathrm{g} / \mathrm{mL})$. The order of the activity of other extracts is $\mathrm{MeOH}$ extract $>\mathrm{CH}_{2} \mathrm{Cl}_{2}$ fraction $>\mathrm{H}_{2} \mathrm{O}$ residue respectively. These results proved there is a correlation between the antioxidant of the tested extracts and their phenolic and flavonoid contents. Also, these results are agreed well with previous studies on other Allium species (Benkeblia, 2005; Kaur et al., 2016).

Table 2: DPPH, ABTS scavenging activity, and total antioxidant capacity of the methanolic extract and certain fraction derived of A. kurrat.

\begin{tabular}{|c|c|c|c|}
\hline $\begin{array}{l}\text { Extract/ } \\
\text { Fraction }\end{array}$ & $\begin{array}{c}\text { DPPH } \\
\text { radical-scavenging } \\
\text { activity SC50 } \\
{[\mu \mathrm{g} / \mathrm{ml}]}\end{array}$ & $\begin{array}{c}\text { ABTS assay } \\
{\left[\text { [mmol Trolox }^{\circledR}\right.} \\
\text { eq./100 g extract] }\end{array}$ & $\begin{array}{c}\text { Total antioxidant } \\
\text { capacity } \\
\text { [mg AAE/g extract] }\end{array}$ \\
\hline $\mathrm{MeOH}$ extract & $57.29 \pm 0.72$ & $31.15 \pm 0.94$ & $170.59 \pm 1.03$ \\
\hline $\mathrm{CH}_{2} \mathrm{Cl}_{2}$ fraction & $66.15 \pm 1.083$ & $38.05 \pm 1.08$ & $160.88 \pm 0.20$ \\
\hline EtOAc fraction & $41.56 \pm 1.06$ & $20.32 \pm 0.19$ & $203.56 \pm 1.07$ \\
\hline $\mathrm{BuOH}$ fraction & $56.13 \pm 1.64$ & $25.98 \pm 0.16$ & $175.45 \pm 0.09$ \\
\hline $\mathrm{H}_{2} \mathrm{O}$ residue & $95.57 \pm 1.44$ & $59.35 \pm 1.49$ & $140.46 \pm 1.09$ \\
\hline
\end{tabular}

The data were expressed as mean \pm standard deviation.

\section{ABTS radical-scavenging activity}

$\mathrm{ABTS}^{+}$is used by several researchers to estimate the scavenging activity of plant extracts by decolorization of ABTS radical by accept the hydrogen atom or electrons from the active compounds in plant extracts (Awika et al., 2003; Abdel-Gawad et al., 2014; El-Sayed et al., 2015; Kaur et al., 2016; Abdel-Hady et al., 2017). The results in Table 2 exhibited that the ethyl acetate fraction has the highest activity $\left(20.32 \pm 0.19\right.$ mmol Trolox $^{\circledR}$ eq./100 g extract) followed by butanolic fraction $(25.98 \pm 0.16$ mmol Trolox ${ }^{\circledR}$ eq./100 g extract) and methanolic extract (31.15 \pm 0.94 mmol Trolox ${ }^{\circledR}$ eq. $/ 100 \mathrm{~g}$ extract). The lowest activity was the water residue $\left(59.35 \pm 1.49 \mathrm{mmol}^{\text {Trolox }}{ }^{\circledR}\right.$ eq. $/ 100 \mathrm{~g}$ extract $)$. These results proved that there is a correlation between the phenolic and flavonoid contents of the tested extracts and ABTS radical-scavenging activity. Also, these results are agreed with Najjaa et al. (2011); Fidrianny (2016) and Safaeian et al. (2017) studies on some Allium species.

\section{Total antioxidant capacity}

It is a simple assay depends on the reduction of Mo (VI) into a green color of phosphate/Mo (V) complex by the antioxidant agents (Kumaran and Karunakaran, 2006). The results demonstrated in Table 2 that the ethyl acetate fraction has higher antioxidant activity $(203.56 \pm 1.07 \mathrm{mg}$ ascorbic acid/g plant extract) followed by the butanolic fraction $(175.59 \pm 1.03$ mg AAE/g extract) followed by the methanolic extract $(170.59 \pm$ $1.03 \mathrm{mg} \mathrm{AAE} / \mathrm{g}$ extract) and the dichloromethane fraction (160.88 $\pm 0.20 \mathrm{mg} \mathrm{AAE} / \mathrm{g}$ extract) while the lowest antioxidant activity was recorded by water residue ( $140.46 \pm 1.09 \mathrm{mg} \mathrm{AAE} / \mathrm{g}$ extract). These results proved that the antioxidant activity of extract and its fractions is correlated with their phenolic and flavonoid contents. Also, these results are agreed with previous studied on other Allium species (Lu et al., 2011; Safaeian et al., 2017).

In this study, the antioxidant activity evaluation of the methanolic extract and the tested fractions of A. kurrat by using DPPH, ABTS radical-scavenging activity and total antioxidant capacity assays .the results revealed that the antioxidant of the tested extracts is correlated with the contents of phenolics and flavonoids. These results are agreed well with other previous studies of Allium species (Safaeian et al., 2017; Fidrianny, 2016).

\section{Cytotoxicity assay}

Life threating diseases are related mainly to cancer (Abdel-Hady et al., 2016). These diseases including cancers are due to reactive oxygen species, lipid peroxidation, and free radicals but their activities can be halted by antioxidants that can delay or inhibit the oxidation process and lipid peroxidation (Singh et al. 2009; Kumar and Santhi, 2012). Polyphenols have been applied for treating cancer patients in traditional Chinese medicine (Mukhtar et al., 2000). And also, saponins have shown effective anticancer potential in various cancer cell lines because they are diverse and complex in the structure which can be shown by inhibiting cell growth and by inducing apoptosis (Xu et al., 2016).

In the present study, preliminary phytochemical screening of the plant extracts revealed the presence of flavonoids, steroids, terpenoids, and saponins in high quantities. Also, the results of the cytotoxic activity of the crude methanol extract of $A$. kurrat and their fractions versus human hepatocellular carcinoma (HepG2) and human colon carcinoma (Caco-2) cell lines using Neutral red assay method was carried out in triplicates. Results in Figure 1 revealed that the butanolic fraction has high activity against the HePG2 and Coca-2 cell lines $\left(\mathrm{IC}_{50}=36.2\right.$ and $44.6 \mu \mathrm{g} /$ $\mathrm{ml}$, respectively) than ethyl acetate fraction $\left(\mathrm{IC}_{50}=48.7\right.$ and 53.7 $\mu \mathrm{g} / \mathrm{ml}$, respectively) and methanol extract $\left(\mathrm{IC}_{50}=58.5\right.$ and 68.4 $\mu \mathrm{g} / \mathrm{ml}$, respectively). These results proved that the antitumour activity of the methanolic extract of A. kurrat do not only depend on the phenolic and flavonoid contents but also on other chemical constituents of this plant especially the saponins (Singh et al., 2009; Kumer et al., 2012; Mukhtar et al., 2009; Xu et al., 2016).

\section{HPLC-ESI-MS analysis}

In the present study, the negative ionization mode of the methanolic extract of $A$. kurrat and the ethyl acetate fraction of was carried out by using HPLC-ESI-MS. The identification of the major chemical compounds of the two extracts was based on their fragmentation pattern and the standards data which that widely reported in the literature. The Neutral losses of 132 (pentose), 162 (hexose), 146 (deoxyhexose), 176 (hexuronic acid), 86 (malonyl 
residue) and 100 (succinyl residue) were identified according to Guarnerio et al. (2012). The results exhibited that the major chemical constituents as shown in Table 3 and 4 and Figure 2 were flavonoids and phenolic acid derivatives.

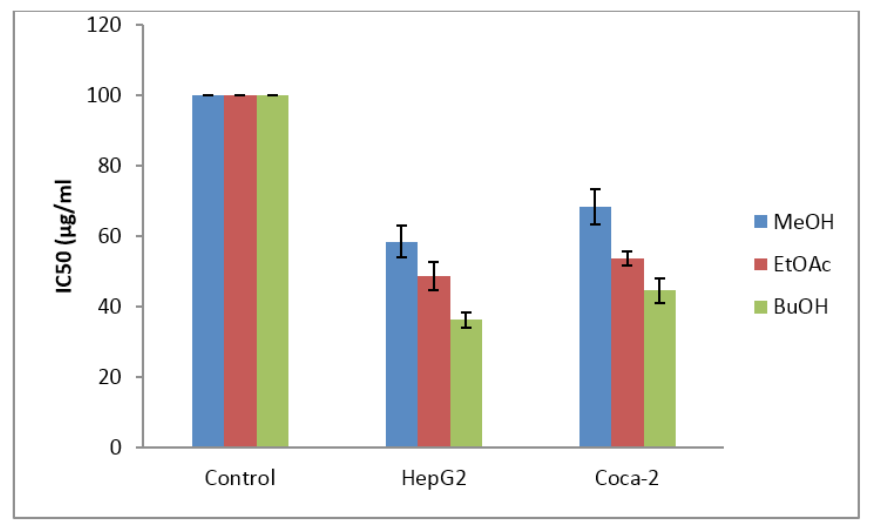

Fig. 1: Cytotoxic inhibition concentration (IC50) of A. kurrat $\mathrm{MeOH}$ ext., EtOAc and $n-\mathrm{BuOH}$ fractions against HepG2 and Caco-2 cell lines.

\section{Flavonoids}

Compound 1 in $\mathrm{MeOH}$ extract with $\mathrm{RT}=21.79 \mathrm{~min}$ exhibited deprotonated molecular ion $\mathrm{m} / z$ $609[\mathrm{M}-\mathrm{H}]^{-}$. The fragment ions at $m / z 447$ [M-H-162] $]^{-}$and 315 [M-H-162-132] means the liberation of hexose and pentoside units. Therefore this compound was tentatively identified as isorhamnetin- $O$-hexosidepentoside (Bonaccorsi et al., 2008). Compound 2 in $\mathrm{MeOH}$ extract $\left(\mathrm{RT}=24.79 \mathrm{~min}\right.$ ) showed precursor ion peak at $\mathrm{m} / \mathrm{z} 787[\mathrm{M}-\mathrm{H}]^{-}$, and fragment peaks at $m / z 625[\mathrm{M}-\mathrm{H}-162]^{-}, m / z 463[\mathrm{M}-\mathrm{H}-(2 \times 162)]^{-}$, $\mathrm{m} / \mathrm{z} 301[\mathrm{M}-\mathrm{H}-(3 \times 162)]^{-}$this means that these liberations of three hexoside units. So, the compound 2 was characterized as Quercetin-tri- $O$-hexoside. Compound 8 in $\mathrm{MeOH}$ extract with RT $=36.32 \mathrm{~min}$ as well as compounds 5 and 7 in EtOAc fraction with $\mathrm{RT}=31.61$ and $36.40 \mathrm{~min}$, respectively which exhibited the same molecular ion peak at $m / z 463[\mathrm{M}-\mathrm{H}]^{-}$and base peak at $m / z$ $301[\mathrm{M}-\mathrm{H}-162]^{-}$, it was indicating the presence of hexoside unit attached with quercetin. Therefore, the compound was identified as Quercetin- $O$-hexoside. These compounds were previously reported in other Allium species (Bonaccorsi et al., 2008; Lee and Mitchell, 2011; Soininen et al., 2012; Farag et al., 2017).

Table 3: Tentative identification of chemical constituents of methanolic extract of A. Kurrat by LC-ESI-MS/MS.

\begin{tabular}{|c|c|c|c|c|c|}
\hline Compound No. & RT (Min) & MW & {$[\mathrm{M}-\mathrm{H}]^{-} m / z$} & MS fragments & Identified compounds \\
\hline 1 & 21.79 & 610 & 609 & 447,315 & Isorhamntin- $O$-hexoside-pentoside \\
\hline 2 & 24.79 & 788 & 787 & $625,463,301$ & Quercetin-tri- $O$-hexoside \\
\hline 3 & 25.63 & 772 & 771 & $609,447,285$ & Kaempferol-tri- $O$-hexoside \\
\hline 4 & 27.38 & 772 & 771 & $609,447,285$ & Kaempferol-tri- $O$-hexoside isomer \\
\hline 5 & 31.22 & 610 & 609 & 447,285 & Kaempferol-di- $O$-hexoside \\
\hline 6 & 35.23 & 948 & 947 & $785,623,447,285$ & Kaempferol- $O$-trihexoside-hexuronoide \\
\hline 7 & 35.82 & 610 & 609 & 285 & Kaempferol-di- $O$-hexoside isomer \\
\hline 8 & 36.32 & 464 & 463 & $301,179,62$ & Quercetin- $O$-hexoside \\
\hline 9 & 38.99 & 610 & 609 & 447,285 & Kaempferol-di- $O$-hexoside isomer \\
\hline 10 & 39.74 & 448 & 447 & 285,151 & Kaempferol- $O$-hexoside \\
\hline 11 & 42.91 & 460 & 459 & 185,179 & Kaempferol- $O$-hexuronoide \\
\hline 12 & 45.25 & 948 & 947 & $771,623,447,285$ & Kaempferol- $O$-trihexoside-hexuronoide isomer \\
\hline 13 & 47.51 & 786 & 785 & 609,285 & Kaempferol-O-dihexoside-hexuronoide \\
\hline 14 & 52.10 & 532 & 531 & 283 & Acacetin-7-O-malonoyl hexoside \\
\hline 15 & 55.61 & 518 & 517 & $455,293,179$ & Unidentified \\
\hline
\end{tabular}

Each compound 3 and 4 in $\mathrm{MeOH}$ extract with $\mathrm{RT}=$ 25.63 and $27.38 \mathrm{~min}$, respectively showed the same deprotonated molecular ion at $m / z 771[\mathrm{M}-\mathrm{H}]^{-}$, and other signals at $\mathrm{m} / z 609$ [M-H-162] $]^{-}, m / z 447$ [M-H-(2×162)]-, and $m / z 285$ [M-H-(3 $\times 162)]^{-}$. Therefore each of these compounds was tentatively identified as Kaempferol-tri- $O$-hexoside. Each of Compounds 5, 7 and 9 in $\mathrm{MeOH}$ extract $(\mathrm{RT}=31.22,35.82$, and $38.99 \mathrm{~min}$, respectively) showed molecular ion peak at $m / z 609[\mathrm{M}-\mathrm{H}]^{-}$. And also, the other signals at $m / z 447$ [M-H-162)] $]^{-}$, and $m / z 285$ [M-H$(2 \times 162)]^{-}$. This means that liberation of two hexoside unit. So, each of these compounds was characterized as Kaempferol-di- $O$ - hexoside. Compound 10 in $\mathrm{MeOH}$ extract with $\mathrm{RT}=39.74 \mathrm{~min}$ as well as compounds 8, 9, 14, and 16 in EtOAc fraction (RT = $39.74,39.74$, and $52.93 \mathrm{~min}$, respectively) exhibited gave the molecular ion peak $m / z 447[\mathrm{M}-\mathrm{H}]^{-}$and base peak at $\mathrm{m} / \mathrm{z} 285$ $[\mathrm{M}-\mathrm{H}-162]^{-}$. Therefore, these compounds were identified as Kaempferol-O-hexoside (Pobłocka-Olech et al., 2016; Farag et al., 2017). Compounds 6 and 12 in the methanolic extract (RT $=35.23,45.25 \mathrm{~min}$, respectively) exhibited the same molecular ion at $\mathrm{m} / z 947[\mathrm{M}-\mathrm{H}]^{-}$, and other fragments at $m / z 785[\mathrm{M}-\mathrm{H}-$ $162]^{-}, m / z 623$ [M-H-(2 × 162)] $]^{-}, m / z 447$ [M-H-(2 × 162)-176] , and $m / z 285[\mathrm{M}-\mathrm{H}-(3 \times 162)-176]$. This means that the loss of 
tri-hexoside units and one hexuronoid unit. So, each of these compounds was tentatively identified as Kaempferol-Otrihexoside-hexuronoide. Compound 13 in $\mathrm{MeOH}$ extract and compound 15 in EtOAc fraction $(\mathrm{RT}=47.51,47.59$ min, respectively) exhibited pseudo molecular ion at $\mathrm{m} / \mathrm{z}$ $785[\mathrm{M}-\mathrm{H}]^{-}$, and three fragment ions at $\mathrm{m} / \mathrm{z} 609[\mathrm{M}-\mathrm{H}-176]^{-}$, $m / z 447$ [M-H-176-162] $]^{-}$and $m / z 285$ [M-H-176- $\left.(2 \times 162)\right]^{-}$ , which represented the liberation of one hexuronoid unit and two hexose units. Therefore, each of these compounds was identified as Kaempferol- $O$-dihexoside-hexuronoide. Compound 11 in $\mathrm{MeOH}$ extract $(\mathrm{RT}=42.91 \mathrm{~min})$ presented pseudomolecular ion at $m / z 459[\mathrm{M}-\mathrm{H}]^{-}$, and another fragment ion at $\mathrm{m} / z 285[\mathrm{M}-\mathrm{H}-174]^{-}$, therefore this compound was identified as Kaempferol-O-hexuronoide (Zhu et al., 2017). Compound 14 in $\mathrm{MeOH}$ extract $(\mathrm{RT}=52.10 \mathrm{~min})$ showed pseudo molecular ion at $m / z 531[\mathrm{M}-\mathrm{H}]^{-}$, as well as fragment ion at $m / z 283[\mathrm{M}-\mathrm{H}-86+162]^{-}$. This indicated the release of malonoylhexoside unit. So, this compound was identified as Acacetin-7-O-malonoyl hexoside (Lin and Harnly, 2010). Compound 11 in EtOAc fraction $(\mathrm{RT}=43.25 \mathrm{~min}$ ) presented a molecular ion at $\mathrm{m} / z 547[\mathrm{M}-\mathrm{H}]^{-}$, and another fragment at $m / z 447$ [M-H-100] $]^{-}$this means loss of the succinic acid unit. Also, fragment ion at $m / z 285[\mathrm{M}-\mathrm{H}-100-162]^{-}$means loss of hexoside unit. Therefore, this compound was tentatively identified as Kaempferol- $O$-succinyl hexoside. Compound 12 in EtOAc fraction ( $\mathrm{RT}=44.25 \mathrm{~min}$ ) exhibited molecular ion at $m / z 489[\mathrm{M}-\mathrm{H}]^{-}$, and other fragment at $m / z 447$ [M-H$42]^{-}$. This means the loss of acetyl group, and the fragment at $m / z 285$ [M-H-42-162] $]^{-}$indicated further losing of hexoside unit. Therefore, this compound was tentatively identified as Kaempferol- $O$-acetylhexoside (Navarro-González et al., 2014). Compound 13 in EtOAc fraction with $\mathrm{RT}=45.42$ min displayed a molecular ion at $m / z 641[\mathrm{M}-\mathrm{H}]^{-}$, and other fragments at $\mathrm{m} / \mathrm{z} 478$ [M-H-163] $]^{-}$which indicating the losing of hexoside unit. Also, a fragment at $m / z 285$ [M-H-163-193] indicated further losing of hydroxyferulic acid unit. Therefore, this compound was tentatively identified as Kaempferol-Ohexosyl-hydroxyferulic acid.

\section{Phenolic acid cerivatives}

Compound 1 in EtOAc fraction $(\mathrm{RT}=20.87 \mathrm{~min}$ ) presented a molecular ion at $m / z 137[\mathrm{M}-\mathrm{H}]^{-}$, and another fragment at $m / z 93$ [M-H-44] $]^{-}$that means losing of carboxylic group. So, this compound was identified as $p$-Hydroxybenzoic acid. Compound 2 in EtOAc fraction ( $\mathrm{RT}=24.79 \mathrm{~min}$ ) showed a molecular ion at $m / z 355[\mathrm{M}-\mathrm{H}]^{-}$, and another fragment at $m / z 193$ [M-H-162] means losing hexose unit but the fragments at $\mathrm{m} / \mathrm{z} 175$ and 161 are characteristic for ferulic acid. So, this compound was identified as Ferulic acid-O-hexoside (Prakash et al., 2007; Barros et al., 2012). Compounds 3 in EtOAc fraction $(\mathrm{RT}=30.89 \mathrm{~min})$ presented a molecular ion at $m / z 279[\mathrm{M}-\mathrm{H}]^{-}$, and the other fragments at $\mathrm{m} / \mathrm{z}$ $163,119)$ corresponded to the $\mathrm{p}$-coumaric acid residue and a small signal for malic acid. Therefore, this compound was assigned as p-Coumaroylmalic acid (Regos et al., 2009).

Overall, LC-ESI-MS analysis of A. kurrat extracts reflected the presence of high amount of kaempferol glycosides and phenolic acid derivatives. These compounds linked to decreasing the risks of many chronic disorders by depicting antioxidant and anticancer (Regos et al., 2009, Zhu et al., 2017; Farag et al., 2017).

Table 4: Tentative identification of chemical constituents of ethyl acetate fraction derived from the methanolic extract of A. Kurrat by using LC-ESI-MS/MS.

\begin{tabular}{|c|c|c|c|c|c|}
\hline Compound No. & RT (Min) & MW & {$[\mathbf{M}-\mathbf{H}]^{-} m / z$} & MS fragments & Identified compounds \\
\hline 1 & 20.87 & 138 & 137 & $93(100 \%), 65$ & p-hydroxybenzoic acid \\
\hline 2 & 24.79 & 356 & 355 & $193,175,161$ & Ferulic acid- $O$-hexoside \\
\hline 3 & 30.89 & 280 & 279 & $119(100 \%), 93$ & p-coumaroylmalic acid \\
\hline 4 & 35.07 & 584 & 583 & 402,193 & Ferulic acid derivatives \\
\hline 5 & 31.61 & 464 & 463 & $301(100 \%), 179$ & Quercetin- $O$-hexoside \\
\hline 6 & 35.73 & 584 & 583 & $493,279,173$ & Unidentified \\
\hline 7 & 36.40 & 464 & 463 & $301(100 \%), 151$ & Quercetin- $O$-hexoside isomer \\
\hline 8 & 39.74 & 448 & 447 & 285,151 & Kaempferol- $O$-hexoside \\
\hline 9 & 40.99 & 448 & 447 & 285,151 & Kaempferol- $O$-hexoside isomer \\
\hline 10 & 42.08 & 578 & 577 & $447,285,162$ & Kaempferol- $O$-pentosyl-hexoside \\
\hline 11 & 43.25 & 548 & 547 & $447,285(100 \%)$ & Kaempferol- $O$-succinoylhexoside \\
\hline 12 & 44.25 & 490 & 489 & $447,327,285$ & Kaempferol- $O$-acetyl hexoside \\
\hline 13 & 45.42 & 642 & 641 & 447,285 & Kaempferol- $O$-hexosyl-hydroxyferulic acid \\
\hline 14 & 46.84 & 448 & 447 & 285,151 & Kaempferol- $O$-hexoside isomer \\
\hline 15 & 47.59 & 786 & 785 & $609,447,285$ & Kaempferol-O-dihexoside-hexuronoide \\
\hline 16 & 52.93 & 448 & 447 & $285(100 \%)$ & Kaempferol- $O$-hexoside isomer \\
\hline
\end{tabular}


<smiles>[R]Oc1cc(-c2oc3cc(O)cc(O)c3c(=O)c2[R])ccc1O</smiles>

1a: $\mathrm{R}=$ Hexoside-Pentoside<smiles>[R2]c1ccc(/C=C/C(=O)O)cc1[R2]</smiles>

$2^{b}: \mathrm{R}_{1}=\mathrm{OCH}_{3}, \mathrm{R}_{2}=$ Hexoside $3^{b}: \mathrm{R}_{1}=\mathrm{H}, \mathrm{R}_{2}=$ Malic acid<smiles>[R]Oc1c(-c2ccc(O)c(O)c2)oc2cc(O)cc(O)c2c1=O</smiles>

$2^{a}: \mathrm{R}=$ Tri-hexoside $8^{a}, 5^{b}: \mathrm{R}=$ Hexoside<smiles>O=C(O)c1ccc(O)cc1</smiles><smiles>[R]Oc1cc(O)c2c(=O)cc(-c3ccc(OC)cc3)oc2c1</smiles>

14a: $R=$ malonoyl hexoside<smiles>[R]c1c(-c2ccc(O)cc2)oc2cc(O)cc(O)c2c1=O</smiles>

3a: $\mathrm{R}=$ Tri-hexoside 5a: $R=$ Di-hexoside 6a: $\mathrm{R}=$ Tri-hexoside-hexuronoid 16a: $\mathrm{R}=$ Tri-hexoside-hexuronoid 11a: $R=$ Hexuronoid

13a, 15b: R= Di-hexoside-hexuronoid

10b: R= Pentosyl-hexoside

11b: R= Succenoyl-hexoside

$12^{b}: R=$ acetylhexoside

$13^{b:} \mathrm{R}=$ Hexosyl-hydroxyferulic acid

a; Compounds in $\mathrm{MeOH}$ extract

$b$; Compounds in EtOAc fraction

Fig. 2: Chemical structures of some compounds of A. kurrat methanolic extract and EtOAc fraction.

\section{CONCLUSION}

This investigation exhibited that the methanolic extract of Allium kurrat has antioxidant properties, so the consumption of this plant should be encouraged by making the people aware of beneficial effects to the system. Also, the methanolic extract of Allium kurrat and its fractions can act as a potential alternative cytotoxic effect against human hepatocellular carcinoma (HepG2) and human colon carcinoma (Caco-2) Cell lines. Therefore, the major constituents of the ethyl acetate fraction and methanolic extract were identified by using HPLC-ESI-MS analysis but the data will be more reliable if the extract will be evaluated by HPLC-DAD (UV-Visible spectrum) together with HPLC-MS.

\section{REFERENCES}

Abd El-Rehem FAA, Ali RFM. Proximate compositions, phytochemical constituents, antioxidant activities and phenolic contents of seed and leaves extracts of Egyptian leek (Allium ampeloprasum var. kurrat). European Journal of Chemistry, 2013; 4(3):185-190.

Abdel-Gawad M, Abdel-Aziz M, El-Sayed M, El-Wakil E, Abdel-Lateef E. In vitro antioxidant, total phenolic and flavonoid contents of six allium species growing in Egypt. J Microbiol Biotech Food Sci, 2014; 3(4):343-346.

Abdel-Hady H, Abdel-Gawad MM, El-Wakil EA. Characterization and evaluation of antioxidant activity of Ocimum canum leaves and its efficiency on Schistosoma mansoni larval stage. Indo Amer J Pharma Res, 2017; 7(11):978-994.

Abdel-Hady H, Abdel-Wareth MT, El-Wakil EA, Helmy EA. Identification and evaluation of antimicrobial and cytotoxic activities of Penicillium islandicum and Aspergillus tamari ethyl acetate extracts. World J Pharmacy Pharma Sci, 2016; 5(9):2021-2039.

Abdel-Hady AA, El-Nahas HA, El Nabarawy SK, Abdel Raouf HA. Evaluation of the Antioxidant Activity and the Acute Oral Toxicity of Three Plant Extracts on Albino Mice. Middle East J Appl Sci, 2014; 4(2):207-216?

Abdel-Lateef EES, Hammam OA, Mahmoud FS, Atta SA, El-Sayed MM, Hassenein HI. Induction of apoptosis in HepG2 by Vitex agnus-castus L. leaves extracts and identification of their active chemical constituents by LC-ESI-MS. Asian Pac J Trop Dis, 2016; 6(7):539-548.

Adão CR, da Silva BP, Parente JP. A new steroidal saponin with antiinflammatory and antiulcerogenic properties from the bulbs of Allium ampeloprasum var. porrum. Fitoterapia, 2011; 82(8):1175-1180.

Akroum S, Bendjeddou D, Satta D, Lalaoui K. Antibacterial, antioxidant and acute toxicity tests on flavonoids extracted from some medicinal plants. Inter J Green Pharm, 2010; 4(3):165-169.

Aqil F, Ahmad I, Mehmood Z. Antioxidant and free radical scavenging properties of twelve traditionally used Indian medicinal plants. Turk J of Biology, 2006; 30(3):177-183?

Atanassova M, Georgieva S, Ivancheva K. Total phenolic and total flavonoid contents, antioxidant capacity and biological contaminants in medicinal herbs. Journal of the University of Chemical Technology \& Metallurgy, 2011; 46(1):81-88.

Awika JM, Rooney LM, Wu X, Prior RL, Cisneros-Zevallos L. Screening methods to measure antioxidant activity of sorghum (Sorghum bicolor) and sorghum products. J. Agric. Food Chem, 2003; 51:6657-6662.

Barros L, Dueñas M, Pinela J, Carvalho AM, Buelga CS, Ferreira IC. Characterization and quantification of phenolic compounds in four tomato (Lycopersicones culentum L.) farmers'varieties in northeastern Portugal homegardens. Plant Foods for Human Nutrition, 2012; 67(3):229-234.

Benkeblia N. Free-radical scavenging capacity and antioxidant properties of some selected onions (Allium cepa $\mathrm{L}$.) and garlic (Allium sativum L.) extracts. Brazilian Archives of Biology and Technology, 2005; 48(5):753-759.

Bonaccorsi P, Caristi C, Gargiulli C, Leuzzi U. Flavonolglucosides in Allium species: A comparative study by means of HPLC-DAD-ESIMS-MS. Food Chemistry, 2008; 107(4):1668-1673.

Bozin B, Mimica-Dukic N, Samojlik I, Goran A, Igic R. Phenolics as antioxidants in garlic (Allium sativum L., Alliaceae). Food 
Chemistry, 2008; 111(4):925-929:

Chang SB, Yang TJ, Datema E, van Vugt J, Vosman B, Kuipers A, de Jong H. FISH mapping and molecular organization of the major repetitive sequences of tomato. Chromosome research, 2008; 16(7):919-933.

Deepa VS, Kumar PS, Latha S, Selvamani P, Srinivasan S. Antioxidant studies on the ethanolic extract of Commiphora spp. Afri J Biotech, 2009; 8(8):1630-1636.

El-Hady FKA, Abdou AM, Abdel-Aziz MS. Isolation, identification and evaluation of antimicrobial and cytotoxic activities of the marine fungus Aspergillus unguis RSPG 204.' Int J Pharm Sci Rev Res, 2014; 28(2):121-127.

El-Sayed MM, El-Hashash MM, Mohamed HR, Abdel-Lateef EES. Phytochemical investigation and in vitro antioxidant activity of different leaf extracts of Salix mucronata Thunb. J Appl Pharma Sci, 2015; 5(12):080-085.

El-Sayed MM, Hashash MM, Abdel-Hady AA, Abdel-Hady H, Abdel-Lateef EE, Morsi EA. Total phenolic and flavonoid contents and antioxidant activity of Lantana camara and Cucurbita pepo (Squash) extracts as well as GC-MS analysis of Lantana camara essential oil. World J Pharm Res, 2017; 6(1):137-153.

El-Serag HB. Hepatocellular carcinoma: an epidemiologic view. J Clin Gastroenterol, 2002; 35:72-78.

Farag MA, Ali SE, Hodaya RH, El-Seedi HR, Sultani HN, Laub A, Eissa TF, Abou-Zaid FOF, Wessjohann LA. Phytochemical Profiles and Antimicrobial Activities of Allium cepa Red cv. and A. sativum Subjected to Different Drying Methods: A Comparative MS-Based Metabolomics. Molecules, 2017; 22(761):1-18.

Fidrianny I. Antioxidant activities from various bulbs extracts of three kinds allium using DPPH, ABTS assays and correlation with total phenolic, flavonoid, carotenoid content. Inter J Res Pharm Sci, 2016; 4(3):438-444.

Ghavam-Haghi F, Sadeghi Dinani M. Isolation and identification of Astragalin and 2-methoxy tyrosol from the bulbs of Allium paradoxum. $\mathrm{J}$ Herbmed Pharmacol, 2017; 6(3):805-822.

Guarnerio CF, Fraccaroli M, Gonzo I, Pressi G, Dal Toso R, Guzzo F, Levi M. Metabolomic analysis reveals that the accumulation of specific secondary metabolites in Echinacea angustifolia cells cultured in vitro can be controlled by light. Plant Cell Rep, 2012; 31:361-367.

Haggag EG, Kamal AM, Abdelhady MI, El-Sayed MM, El-Wakil EA, Abd-El-hamed SS. Antioxidant and cytotoxic activity of polyphenolic compounds isolated from the leaves of Leucenia leucocephala. Pharma Biol, 2011; 49(11):1103-1113.

Kaur G, Gupta V, Christopher AF, Bansal P. Antioxidant Potential of Most Commonly Used Vegetable-Onion (Allium cepa L.). J Compl Alter Med Res, 2016; 1(1):1-5.

Krishnamurthi K. 17-screening of natural products for anticancer and antidiabetic properties. Cancer. 2007; 3(4):69-75.

Kumar D, Santhi R. Antioxidant and cytotoxic effects of hexane extract of Morindapubescens leaves in human liver cancer cell line. Asian Pac J Trop Med, 2012; 5(5):362-366.

Kumaran A, Karunakaran J. In vitro antioxidant activities of methanol extracts of five Phyllanthus species from India. LWT, 2006; 40:344-352.

Lee J, Mitchell AE. Quercetin and isorhamnetin glycosides in onion (Allium cepa L.): varietal comparison, physical distribution, coproduct evaluation, and long-term storage stability. J Agric food chem, 2011; 59(3):857-863.

Lin LZ, Harnly J M. Identification of the phenolic components of chrysanthemum flower (Chrysanthemum morifolium Ramat). Food Chemistry, 2010; 120(1): 319-326.

Lu X, Wang J, Al-Qadiri HM, Ross CF, Powers JR, Tang J, Rasco BA. Determination of total phenolic content and antioxidant capacity of onion (Allium cepa) and shallot (Allium oschaninii) using infrared spectroscopy. Food Chemistry, 2011; 129(2):637-644.

Malairajan P, Gopalakrishnan G, Narasimhan S, Veni KJK Analgesic activity of some Indian medicinal plants. J Ethnopharm, 2006; 106(3):425-428.
Marinova D, Ribarova F, Atanassova M. Total phenolics and total flavonoids in Bulgarian fruits and vegetables. Journal of the University of Chemical Technology and Metallurgy, 2005; 40(3):255-260.

Mukhtar H, Ahmad N. Tea polyphenols: prevention of cancer and optimizing health. Am J Clin Nutr, 2000; 71:1698s-1702s.

Najjaa H, Zerria K, Fattouch S, Ammar E, Neffati M. Antioxidant and antimicrobial activities of Allium roseum L."Lazoul," a wild edible endemic species in North Africa. Inter J food Prop, 2011; 14(2):371-380.

Navarro-González I, González-Barrio R, García-Valverde V, Bautista-Ortín A B, Periago M J. Nutritional composition and antioxidant capacity in edible flowers: characterisation of phenolic compounds by HPLC-DAD-ESI/MSn. Inter J Molecular Sci, 2014; 16(1):805-822.

Pobłocka-Olech L, Głód D, Żebrowska ME, Sznitowska M, Krauze-Baranowska M. TLC determination of flavonoids from different cultivars of Allium cepa and Allium ascalonicum. Acta Pharmaceutica, 2016; 66(4):543-554.

Prakash D, Singh BN, Upadhyay G. Antioxidant and free radical scavenging activities of phenols from onion (Allium cepa). Food Chemistry, 2007; 102(4):1389-1393.

Regos I, Urbanella A, Treutter D. Identification and quantification of phenolic compounds from the forage legume sainfoin (Onobrychisviciifolia). J Agric food chem, 2009; 57(13):5843-5852.

Repetto G, del Peso A, Zurita JL. Neutral red uptake assay for the estimation of cell viability/cytotoxicity. Nat Protoc, 2008; 3:1125-31.

Ricci-Vitiani L, Lombardi DG, Pilozzi E, Biffoni M, Todaro M, Peschle C, De Maria R. Identification and expansion of human coloncancer-initiating cells. Nature, 2007; 445(7123):1-5.

Saeed N, Khan MR, Shabbir M. Antioxidant activity, total phenolic and total flavonoid contents of whole plant extracts Torilis leptophylla L. BMC Complement. Altern. Med, 2012; 12(1):221.

Safaeian L, Zolfaghari B, Aghaye-Ghazvini M, Behnampour M. Evaluation of fibrinolytic and antioxidant effects of Allium elburzense bulb extracts. Avicenna journal of phytomedicine, 2017; 7(3):223-231.

Sasaki YF, Kawaguchi S, Kamaya A, Ohshita M, Kabasawa K, Iwama $\mathrm{K}$, Taniguchi $\mathrm{K}$, Tsuda $\mathrm{S}$. The comet assay with 8 mouse organs: results with 39 currently used food additives. Mut Res/Gen Toxicol Envir Mutag, 2002; 519(1):103-119.

Sharaf A, Abdou I, Hassan M, Yossif M, Nigm S. Pharmacochemical studies on Allium kurrat. Qualitas Plantarum et Materiae Vegetabiles, 1969; 17(4):313-320.

Singh BN, Singh BR, Singh RL, Prakash D, Singh DP, Sarma BK, Upadhyay G. Singh HB. Polyphenolics from various extracts/fractions of red onion (Allium cepa) peel with potent antioxidant and antimutagenic activities. Food Chem Toxicol, 2009; 47(6):1161-1167.

Škerget M, Majhenič L, Bezjak M, Knez Ž. Antioxidant, radical scavenging and antimicrobial activities of red onion (Allium cepa L) skin and edible part extracts. Chem biochem eng quart, 2009; 23(4):435-444.

Soininen TH, Jukarainen N, Julkunen-Tiitto R, Karjalainen $\mathrm{R}$, Vepsäläinen JJ. The combined use of constrained total-line-shape $1 \mathrm{H}$ NMR and LC-MS/MS for quantitative analysis of bioactive components in yellow onion. J Food Comp Anal, 2012; 25(2):208-214.

Xu XH, Li T, Fong CMV, Chen X, Chen XJ, Wang YT, Hang M, $\mathrm{Lu}$ JJ. Saponins from Chinese medicines as anticancer agents. Molecules, 2016; 21(10):1326-135.

Zhu L, Peng Z, Zhang X, Yang J, Lai X, Yang G. Determination of Polyphenols in Lycium barbarum Leaves by High-Performance Liquid Chromatography-Tandem Mass Spectrometry. Analytical Letters, 2017; 50(5):761-776

How to cite this article:

Abdel-Hady H, El-Sayed MM, Abdel-Gawad MM, El-Wakil EA, Abdel-Hameed ES, Abdel-Lateef EEL. LC-ESI-MS analysis, antitumor and antioxidant activities of methanolic extract of Egyptian Allium kurrat. J App Pharm Sci, 2018; 8(07): 085-092. 